\title{
Legal Protection of E-Wallet User in Digital Transaction
}

\author{
Sunaryo $^{1}$, Hanifah Nuraini ${ }^{2}$ \\ \{sunaryo.1960@fh.unila.ac.id ${ }^{1}$, hanifahwinartin10@gmail.com² ${ }^{2}$ \\ Faculty of Law Lampung University, Bandar Lampung, Indonesia ${ }^{1}$, Post Graduated Faculty of Law \\ Lampung University, Bandar Lampung, Indonesia ${ }^{2}$
}

\begin{abstract}
Digital payment system combines technological element that has characteristic of effectiveness and efficiency in commercial transaction. Electronic wallet is an electronic service that is used to collect digital payment funds and store payment data. As a digital payment system, e-wallet is categorized in a micro scale payment which designed to serve small payments with high frequency. In practice, e-wallet has some risks such as malfunction, duplication of devices, repudiation. The risks are departing on the problem of digital e-wallet system performance that requires involvement by many stakeholders, so the complexity in business interactions and the system manage its risks. Legal protection of e-wallet users through legal arrangements creates interoperability in digital performance e-wallet payment system to give better digital payment. The right interoperability can optimize stakeholder capabilities in coordinating with each other. The effectiveness of coordination is built by system standardization in regulation instrument that can guarantee e-wallet legal protection.
\end{abstract}

Keywords: E-wallet, Legal Protection, Digital Transaction

\section{Introduction}

Digital transactions confront two parties with buyer and seller interests within information technology framework. Trading interests available for goods and services carried out with particular payment instrument. The payment instrument commonly used is cash payment as the rupiah exchange rate. However, the use of cash payment would causes some problems, especially high cash handling, robbery/theft, practicality and deployment of counterfeit money [1]. That risk eventually led to a renewal of payment instruments known as digital payment model or electronic payment [2].

The digital payment system is an innovation to designed facilitate access payments in digital transaction. Awais Ahmed said the digital payment system is a third party that helps transfer fund from payer to recipient [3]. This function then can make differentiates among digital payments and conventional payments. Cash or conventional payments tend not to require intermediaries in carrying out payment transactions and only reach some particular transaction services. Meanwhile, digital payment positions the system or operator as a third party in the transaction. This is intended that information technology can help payment performance more quickly and flexible. One of the types of digital payments available in Indonesia is Electronic wallet. 
Electronic wallet (e-wallet) is defined as a software application that allows users to store payment instrument data, make digital payments and to be used for various types of digital transactions [4]. E-wallet applications are based on the type of data storage which called as server based. Digital payments using software like e-wallet can make an easier for users to access payments for payments to persons (P2P) and payments to business (P2B) [5]. Easiness of access refers to transaction efficiency without cash and speed up payment process.

E-wallet is a digital payments system that connect the rights and duty of the parties when carrying out transactions. These right and duty are emerged because of an agreement. For example, in a purchase contract, the buyer needed to pay a price to get the goods provided by the seller. This duty is carried out by the buyer using an e-wallet. Furthermore, e-wallet must be forward payments by transferring funds from the buyer to the seller. This case arises legal relationship between the buyer and the e-wallet and the e-wallet and the seller. The three parties establish an interconnection in a digital payment agreement. That's agreement occurs when the user registers an account into e-wallet application and the buyer is automatically deemed to have agreed to any terms of e-wallet. The substance of these provisions includes matters relating to the implementation and application of e-wallets including provisions regarding protection and management of risks or particular problems.

The risk of using e-wallet can happen because of the complexity of the interconnection of e-wallet systems. The complexity is due by many payment instruments involved. Some types of risks that can arise in the e-wallet application include fraud risk, technology risk, credit risk, reputation risk, and liquidity risk [6]. The quantity of risk places the management risk function and role into very important position. The function and role of management risk in e-wallet providers is becoming important with the existence of various risks that have the potential losses to impact the users of e-wallet services [6]. This research will discuss the construction of e-wallet user protection from law perspective. Reviewing the legal position in e-wallet management system which includes technological and economic elements, as well to analyse the effectiveness of risk management through standardization of the e-wallet system.

\section{Literature Review}

With the above focus area in view, the existing literature on the subject was studied, that is displays certain analyzes of the development and protection of e-commerce related to digital payments purse. Some of this previous research can also be a reference for renewable research that is concerned with e-wallet legal protection studies.

a. The Mobile Wallet Ecosystem - A Challenge for Retail Banks? [10]

Technological innovation, recent regulatory initiatives and mass consumers "changing expectations are quickly re-shaping the payments" sector, paving the way to a more open environment where even non-banking players see a huge opportunity to gain momentum and disrupt the incumbents, namely the financial institutions. This paper contributes to provide a better understanding of the mobile wallet ecosystem, also analyzing a set of four business cases so to identify potential sources of competitive advantage for retail banks in a market characterized by an increased nonbank competition. Mobile wallet platforms can be a powerful tool for banks to cope with the customer-centric approach. The structure of the paper analyse the recent trends in the financial services industry, involving the entry of new players (Fintech); the evolution of payments in the market; the concept of ecosystem applied to the new payment landscape; and it outlines the banks" roles in the new mobile payment environment. 
b. Legal Protection for Consumers in E-Commerce Transactions [5]

E-commerce is a form of trade that has special characteristics in transactions, namely the use of internet technology media without bringing together sellers and buyers. Research conducted by Bagus Hanindyo Mantri in his thesis resulted in the conclusion that The Act Number 8 Year of 1999 concerning Consumers Protection has not been able to protect consumers in e-commerce transactions due to the limited understanding of business actors who are only specifically in Indonesia and the limitations of regulated consumer rights. Legal protection for consumers should regulate matters including legal protection from the perspective of business actors, consumers, products and transactions.

\section{Methods}

The type of research used in this article is normative legal research with the object of clinical legal research [7]. The clinical legal research study begins with describing the legal fact of e-wallet application, then looks for solutions to legal protection problems through critical analysis of existing legal norms, and then finds concrete laws to solve problems related to risks and their prevention. In this study, the author uses conceptual approach [8] and statute approach [9] that departs from the views of jurists or doctrines. This conceptual approach will provide an overview of the mechanisms for implementing e-wallets. Meanwhile, in order to obtain a normalization description of a legal issue, it is necessary to examine the approach of the relevant legislation, such as the Indonesia Civil Law, the Banking Law, the Consumer Protection Law and the Bank Indonesia Regulations. The type of data used is secondary data, consisting of laws and regulations related to legal protection, contract law, and regulations related to the digital financial service provider sector. Meanwhile, secondary data is obtained through literature regarding theory, expert opinion, and journals regarding legal protection and electronic transaction activities.

\section{Result and Discussion}

Mobile payment is one of the digital payment models in Indonesia. Types of mobile payments vary depending on their functions and uses. Mobile payment is different from mobile banking even though it has similar facilities, namely as mobile money, mobile transfer and mobile wallet. Mobile payments can used via mobile devices without requiring a bank account. That's make everyone who has a mobile device can use mobile payments without a bank account. One of the mobile payment facilities is a mobile wallet which is implemented through an e-wallet application [11]. In other words, e-wallets can only be used with intermediaries for telecommunications technology or other electronic devices.

The integration of telecommunication technology (cell phones) and payment is a complex process and requires coordination of various players and stakeholders. Every stakeholder has their respective roles according to their competency spectrum. That stakeholder including customers, financial service providers (FSPs), payment service providers (PSPs), merchants, transmission networks, mobile devices, regulators, product standardization, trusted service managers, and application development [6]. This coordination 
including several aspects including economic aspects, legal aspects, and information technology and telecommunication aspects.

Based on economic perspective, it means that customers (consumers) and merchants control an important role in the digital payment system. This can be happened because main of e-wallet implementation desire and interests of the transactors. Without the interest consumer transaction e-wallets is meaningless. In the application of e-wallets, there are digital payment technology that must be supported by technological aspects by existing on wireless networks, the availability of digital financial services and digital payment services. Information technology and telecommunications networks are actualized with digital payment technology features through cellular devices. On the next level, law becomes the central connector between the interests of transactors and operators of the digital e-wallet system. The law step to connect these relations to establish regulations and standardize systems and products.

\subsection{Digital Payment System of Operation E-wallet in Indonesia}

The implementation of E-wallets in Indonesia is based on the interests of the micro payment business. These business interests is to accommodate people's daily transaction needs. In addition, the trend of using smartphones is also a factor in the development of ewallets. Metasearch site iPrice Group and App Annie [12] one of data analysis company noted that the development of e-wallet applications in Indonesia increased by about $50 \%$ from the fourth quarter of 2017 to the second quarter of 2019.

E-wallets are built from the interconnection between stakeholders that form the structure of the digital system. Called as a digital system structure because the process of transmitting and processing e-wallet data is carried out by wireless networks and electronic devices. For example, consumers who want to buy products with an e-wallet application will be met with a Payment Gateway User Interface in the form of an order checkout display. Furthermore, the payment gateway through a digital network transmits checkout information to the e-wallet organizer. After the information is received, the e-wallet organizer confirms the payment by displaying token colomn or the pin. By entering the e-wallet pin number, the nominal information paid will be sent to the seller's mobile payment or acquirer. The balance that goes to the seller's account shows the successful transfer of buyer's funds through the digital network.

Refers to the Smart Card Alliance categorizations, there are several mobile payment models that can be applied in Indonesia, namely operator-centric models (such as mytelkomsel, myIM3), bank-centric models (such as Go Mobile by CIMB, BNI Mobile Banking, JakOne Mobile etc.), peer to peer models(such as Gopay, Ovo, Shopee pay) and the collaboration models (Sakuku, Dana, Jenius etc.). The exact models for the application of an e-wallet type of mobile payment is the peer to peer and collaboration models.

In the peer to peer models, independent service provides mobile payments between customers or between customers and agents. The peer to peer model is an innovation created by the payment industry newcomers who are trying to find ways to process payments without the use of existing wire transfers and bank card processing networks.

a. Scenario 1: Providers distribute contactless cards / devices to customers and point of sale equipment (hereinafter written POS) to agents in a closed loop model.

b. Scenario 2: Provider deploys a mobile payment application to activate NFC mobile devices. 
c. Scenario 3: A peer to peer service provider using an existing online application. No POS equipment required

Meanwhile, the collaboration models integrate the roles between banks, cellular operators and other stakeholders in mobile payment services, including third parties who can potentially control and supervise the deployment of mobile applications. This model includes two possible scenarios:

a. Scenario 1: A mobile operator partner with one bank collaborates to offer m-payment services to a particular bank

b. Scenario 2: The representation of Industry associations mobile operators and financial institutions negotiate and set standards for applications that are on the secure element on mobile devices that allow several types of cards from different banks to be used.

The peer to peer model is found in the e-wallet type of close loop system, it means the use of e-wallets is limited to transactions for products presented by the platform concerned. For example, in using Gopay, consumers can use the Gopay e-wallet only on features or services belonging to the Gojek platform such as Gofood, Goshop, Gosend and so on. This type of e-wallet is made by a fintech company to facilitate the flow of digital service transactions in one ecosystem. This is different from the collaboration model which is able to integrate several types of transactions, both credit and debit, in one application. Some of the types of transactions referred to include digital transaction services in an open loop system. Consumers can function e-wallets like conventional wallets, which are digital fundraising services that can be used as digital payment instruments. E-wallet Dana, for example, consumers can use it for transaction services that are not limited to applications. This means that digital money in the Dana application is not closed, but more flexible. Because this type of e-wallet was not born from a fintech company that had previously provided certain digital services. The two types basically reflect the form of e-wallet use in Indonesia. Although different, both the peer to peer model and the collaboration model have their respective advantages. The advantages presented by each model will depend on the preferences of the people as users.

\subsection{Legal relation of the parties for E-wallet Operation}

Electronic transaction with digital payments is form of the law that configurations a legal relation between the parties. The law is meant an action that appear from the agreement as a legal relation between two or more legal subjects in the field of property law. The question is whether the actions of someone who connect to digital payment technology like e-wallet can be called as a legal agreement? When technology is not a legal subject.

Digital payment agreement with e-wallet involves a system structure. Collaboration among individual subjects and the system puts the concept of agreement at a uncertain point. This happens because the system is formed by combination of tools and technology that obscures the interaction between legal subjects. For example, buyers who use e-wallets will believe that themselves interacting with digital application technology without understanding that e-wallet are formed by a legal entity that is required to the legality of operate. Thus, the law in the operation of e-wallets can fulfil the requirements of the agreement if the e-wallet issuer is a licenced as legal entity.

Provisions regarding the legality of e-wallet operation are stipulated in national regulations through Bank Indonesia Regulation 18/40/PBI/2016 (herein after written as PBI PPTP). This regulation states that in order to operate an e-wallet, the issuing company must obtain a licence from Bank Indonesia. One of the main requirements for obtaining this permit is to legalize the e-wallet company in the form of a legal entity that is officially registered with 
the Ministry of Law and Human Rights [13]. This provision implies the reach of the agreement in use of digital e-wallet payments.

The commitment to implementing the e-wallet digital payment system creates a legal relationship between the parties involved. The following is a scheme of legal relation among consumers, e-wallet providers, merchants, which is possible with issuers and acquirers.

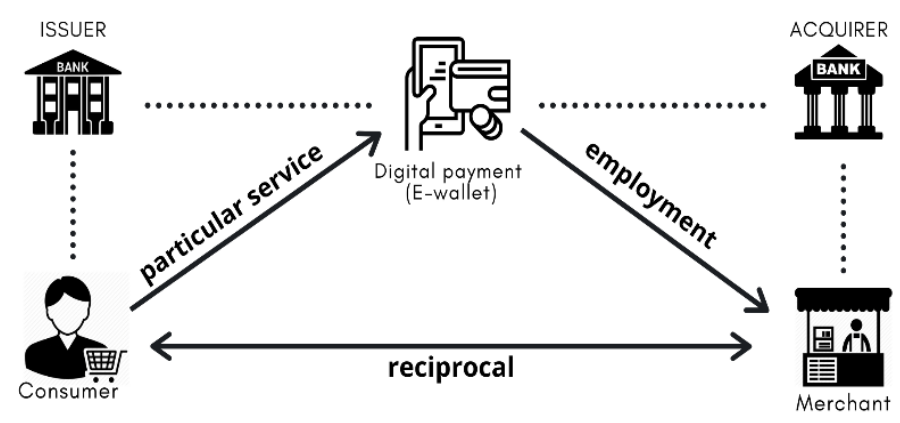

Figure 1. Legal relation in Operating E-wallet

In the relation between the e-wallet provider and the user or account owner, the fundamental responsibility of the provider is to offer a guarantee that the electronic money is holds can be used as a means of payment for affiliated merchants. The object of this type may be possible to be complete with the employment contract or more specifically a particular services provision contract. [14]. E-wallet operators will take action in the form of digital payment services where the e-wallet provider will get a fee for the service they do. Particular service provision contracts are coordinative, meaning that users and e-wallet operators coordinate with each other through features on digital devices. Apart from the agreement for the provision of certain services, the relation between users and operators of e-wallets in terms of form can be classified as a standard contract. This agreement is created when someone agrees to bind themselves to an agreement that has been established by the other party [15]. In other words, dealing in the standard contract will occurs when someone input their data to the e-wallet application, and for a moment, that person's status changes to an e-wallet user. This situation is interpreted as a form of user deal with all provisions set by the e-wallet operator.

It's different with the relation between e-wallet providers and merchant. In this relation, merchant retail must already have collaboration with e-wallet providers to be able to use ewallet facilities as an alternative consumer payment. The cooperation makes merchants an affiliated party with e-wallets. The right contract to fulfil this act is a employment services contract. According to Abdulkadir Muhammad, the implementation of employment agreement is the realization or fulfilment of the rights and duties that have been agreed upon by the parties so that the agreement can achieve these goals [16]. In essence, this contract will regulate action in business activities between merchants and e-wallet providers.

Furthermore, the relation between e-wallet providers and issuer banks (consumer-owned banks) and/or acquirer banks (banks with merchant accounts) is related to the funds transfer from bank accounts that are converted to be electronic money into digital payment instrument accounts or bank accounts of other parties. Funds transfer between bank accounts is optional. This mean the use of the top up balance feature in the e-wallet application can be done in various ways, not only by transferring via bank accounts. This is because e-wallets have similar characteristics with electronic money. Funds stored in e-wallets are not bank deposits, 
because the value of money deposited by users to e-wallet service providers is not placed in bank account [17].

This function of e-wallets in this case is limited to storing electronic money and storing data on payment instruments. This act can be complemented by an employment contract. The electronic money storage comes from the user's bank account. In other words, the relation between issuers, e-wallet providers and acquirers requires employment contracts to link each other. Without cooperating with banking institutions, e-wallet operators cannot function properly.

The relation between the issuer and the consumer is as well as the acquirer and the merchant, both of which concern the relation between the customer and the banking company [18]. The appropriate contract to fulfil this action is the banking contract in general. And for the main legal relation between consumers and merchants will be bound by an agreement called a reciprocal contract [14].

Sequence of legal relation will lead to the agreement purpose of the parties. In achieving this purpose, each party involved cannot be separated from legal responsibility. Legal liability is closely related to errors, omissions or omissions in the implementation of the agreement [19]. The interconnection of digital payment agreements between consumers, e-wallet providers and merchants provides will give protection for the implementation of transactions for any problems that occur through guarantees of legal liability. Each party is responsible for the obligations it carries. Violating the agreement means being responsible for the consequences of losses suffered by the other party. The ideal and appropriate form of agreement can optimize the protection of the implementation of the agreement through the guarantee of legal liability.

\subsection{The construction of legal protection for e-wallet operations}

Besides providing various benefits and conveniences for users, e-wallet digital payment system actually also has various potential risks. The weakness of using e-wallets lies in the acceleration of the digital system itself. The adopting of digital systems into payment instruments will combine several methods of electronic payment systems by connecting to each other via the internet, including credit card networks, debit cards, electronic money and e-wallets based on stored values, smart cards or other technologies [17]. Digital interconnection then creates potential system risks which are very different from conventional payments.

The risk of implementing e-wallet has an impact on users and service providers. Types of risk that occur include fraud risk, technology risk, credit risk, liquidity risk, reputation risk, money laundering risk, and regulatory compliance risk. This risk arises because of vulnerabilities in e-wallets that can pose threats in the form of network hacking, data theft, virus infections, illegal transactions, and abuse of authority. To reduce the risks that arise, mitigation and prevention efforts through standardization of digital payment systems need to be carried out massively and systematically. The details of risk analysis that can occur in ewallet operations will be explained in the table below.

Table 1. The risk of E-wallet Operations

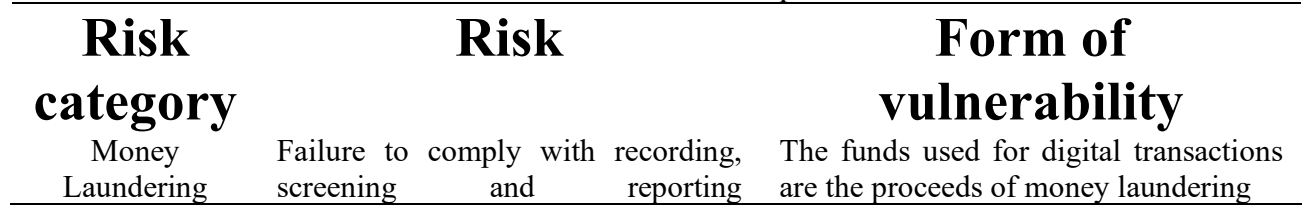




\begin{tabular}{|c|c|c|}
\hline & $\begin{array}{l}\text { requirements intended to detect } \\
\text { financial crimes, prevent illegal } \\
\text { cross-border payments and prevent } \\
\text { terrorist financing }\end{array}$ & \\
\hline Fraud & $\begin{array}{l}\text { Failure to prevent or obstruct } \\
\text { unauthorized } \\
\text { interception of transactions, } \\
\text { information or other fraudulent } \\
\text { activities caused by weak networks } \\
\text { and systems. }\end{array}$ & $\begin{array}{l}\text { Fake transactions by third parties that } \\
\text { steal user data }\end{array}$ \\
\hline Compliance & $\begin{array}{l}\text { Failure to comply with consumer } \\
\text { protection laws and other regulations }\end{array}$ & $\begin{array}{l}\text { Making digital payment instruments a } \\
\text { tool for money laundering and / or } \\
\text { illegal transactions }\end{array}$ \\
\hline Credit & $\begin{array}{l}\text { Possible losses from failure to verify } \\
\text { funds sender, fund recipient or e- } \\
\text { wallet organizer }\end{array}$ & $\begin{array}{l}\text { Change the transaction scanning } \\
\text { machine settings (such as POS and } \\
\text { NFC scanner) with the intention of } \\
\text { stealing customer data and committing } \\
\text { fake transactions }\end{array}$ \\
\hline Liquidity & $\begin{array}{l}\text { The theft of funds by third parties } \\
\text { occurs as a result of the easier use of } \\
\text { e-wallet services in conducting } \\
\text { financial transactions }\end{array}$ & $\begin{array}{l}\text { The number of transactions that move } \\
\text { funds from one financial institution to } \\
\text { another }\end{array}$ \\
\hline Technology & $\begin{array}{l}\text { Failure to protect information due to } \\
\text { adoption of unclear technology, } \\
\text { spam, theft of services, theft of } \\
\text { services and content, and software } \\
\text { piracy }\end{array}$ & $\begin{array}{l}\text { Network and system hacking results in } \\
\text { transaction failures, data stolen, and lost } \\
\text { funds }\end{array}$ \\
\hline Reputation & $\begin{array}{l}\text { Negative consumer experience can } \\
\text { reflect an organizer's bad reputation } \\
\text { or reduce the level of public trust }\end{array}$ & $\begin{array}{l}\text { Poor risk management services, } \\
\text { inadequate access to complaint } \\
\text { mechanism. }\end{array}$ \\
\hline
\end{tabular}

The types of that risks, require appropriate risk management measures to minimize losses. Risk management actions are carried out by risk mitigation that is focused on reducing the potential for risk [20]. An effort that can be taken to reduce risk are by creating regulator standards that determine the term of operation. The regulatory standards must accommodate the interest of service provider and e-wallet users. This standardization is also intended to create a smooth, safe, efficient and reliable payment system that emphasizes the fulfilment of the prudential principles and adequate risk management while still taking account into national interest and consumer protection.

International Organization for Standardization or what is called ISO is a federation of national standards around the world that relies on the ISO committee to create particular standards. ISO 12812 is document that contains requirements, standards and recommendations for the implementation of digital payments [21] is divided into five documents. The object of ISO 12812 regulation relates to the mechanism for implementing a digital payment system, including payment by e-wallet. ISO 12812 basically contains about:

a. Facilitate and promote interoperability between the different components or functions building mobile financial services;

b. Build a safe environment so that consumers and merchants can trust the service and allow the mobile finance services providers to manage their risks; 
c. Promote consumer protection mechanisms including - fair contract terms, rules on transparency of charges, clarification of liability, complaints mechanisms and dispute resolution;

d. Enable the consumer to choose from different providers of devices or mobile financial services - including the possibility to contract with several mobile financial service providers for services on the same device;

e. Enable the consumer to transfer a mobile financial service from one device to another one (portability);

Standards set by ISO 12812 can serve as guidelines for implementing mobile payments for all digital payment company developers in the world. This guide was created to assist digital platforms in structuring a quality digital system. By setting this international standard, it is hoped that digital payment service developers will be able to build reliable and trusted technology capabilities. Risk management, complaint mechanisms and consumer protection are among the prerequisites for international standards that must be met by digital payment providers including e-wallet operators. ISO 12812 is a provision that establishes standards for the development and implementation of digital payments, but its nature is not binding and coercive. In other words, ISO does not require every digital payment provider to implement the standards it sets. ISO standardization is manifested in the form of certification to implementing companies that have met the requirements. This certification serves to increase the brand of digital products and increase consumer trust.

In Indonesia, the standard of reliable e-wallet operation is embodied in normative policies in the form of regulations. This normative policy is an implementation of legal protection for e-wallet users. Legal protection for e-wallet users in digital payment activities is carried out in two forms, namely preventive protection and repressive protection. Preventive protection, namely through rules set by the government and in the form of an agreement between the e-wallet provider and the user. Repressive protection is an effort to protect the law through dispute resolution in court as well as alternative dispute resolution [22].

The standard of implementing an accountable and reliable e-wallet is implemented by fulfilling an adequate and quality operational system. The requirements for realizing the quality of the operational system are listed in Article 18 of the PBI PPTP which essentially requires the operator to fulfil:

a. Effective and consistent risk management

b. Information system security standards

c. The operation of processing domestic payment transactions

d. Consumer protection

System security standards by e-wallet operators can be met by implementing data security and information on payment instruments, optimizing systems and procedures for activation and use of e-wallets and implementing fraud detection systems. This standard is mandatory and must be fulfil by e-wallet service providers. The mandatory phrase in a Bank Indonesia Regulation is intended to demand that operators apply ideal security principles. The application of this ideal security principle is necessary in terms of overcoming and reducing risks arising from system vulnerabilities or weaknesses such as fraud risk, credit risk and technology risk.

The relation between organizers and consumers often creates unreal bargaining [23] he imbalance in this relationship is caused by the presence of asymmetric information and power imbalances. In this case, e-wallet operators have a more dominant position than consumers. Bank Indonesia consciously understands this condition. Therefore, in order to maintain and 
regulate the smooth operation of the digital payment system, Bank Indonesia in accordance with its authority stipulates a special regulation regarding consumer protection for payment system services in Bank Indonesia Regulation Number 16/1 / PBI / 2014 (hereinafter written as PBI 16/2014)

PBI 16/2014 provisions were created to accommodate consumer protection principles that apply as international standards. These principles include the principles of fairness and reliability, transparency, protection of personal data and the effective handling and resolution of consumer complaints (complaint mechanism). The implementation of consumer protection principles by the organizers is expected to create a balanced bargaining position between ewallet operators and consumers, which is the embodiment of the principle of equality in the agreement. In addition, consumer protection for digital payment system services can also prevent various risks, such as reputation risk, compliance risk, fraud risk, and etc.

\section{Conclusion}

Digital transactions combine the functions of information technology with people's economic activities. Digital payment systems are promoted as digital transaction innovations to create payment system updates that reflect technological sophistication via mobile devices. E-wallets are a form of digital payment that exists in Indonesia. The use of e-wallet which is very easy and practical makes it much in demand by the public. However, behind its simplicity, e-wallets also have a several risks that can potentially harm users. These risks include fraud risk, technology risk, credit risk, liquidity risk, reputation risk, money laundering risk and compliance risk. To overcome this risk, a well-standardized digital payment system policy is needed. Standardization is carried out to create an accountable and reliable operational quality for e-wallet operations. The digital payment system policy is set out in the form of a Bank Indonesia Regulation. In this regulation, the standardization of the digital ewallet payment system includes matters such as licensing, determination of quality risk management, information system security standards, and compliance with the principles of consumer protection for payment system services.

\section{References}

[1] A. Hidayat, A. Firmansyah, F. Aulia, and Dkk, "Upaya Meningkatkan Penggunaan Alat Pembayaran Non Tunai Melalui Pengembangan E-Money,” 2006.

[2] S. Sumanjeet, "Emergence of payment systems in the age of electronic commerce: The state of art," in 1st South Central Asian Himalayas Regional IEEE/IFIP International Conference on Internet, AH-ICI 2009, 2009, vol. 3, no. 3, pp. 18-40, doi: 10.1109/AHICI.2009.5340318.

[3] A. Ahmed, A. Aziz, and M. Muneeb, "Electronic payment system: A complete guide," $J$. Multidiscip. Sci., vol. 1, no. 2, pp. 1-17, 2019, doi: 10.33888/jms.2019.121.

[4] G. Sameer, N. Marie-Claude, and R. Kausik, "Gauging the disruptive potential of digital wallets," McKinsey on Payments, vol. 8, no. 21, pp. 3-11, 2015.

[5] B. H. Mantri, "PERLINDUNGAN HUKUM TERHADAP KONSUMEN DALAM TRANSAKSI E-COMMERCE," 2007.

[6] R. Untoro, A. Trenggana, and K. Dewi, "Pemetaan Produk Dan Risiko Pembayaran Bergerak ( Mobile Payment ) Dalam Sistem Pembayaran Di Indonesia," Pemetaan Prod. Dan Risiko Pembayaran Berger. (Mobile Payment) Dalam Sist. Pembayaran Di Indones., pp. 1-74, 2013. 
[7] Bachtiar, Metode Penelitian Hukum, no. 1. 2018.

[8] D. L. Sonata, "Metode Penelitian Hukum Normatif dan Empiris: Karakteristik Khas Dari Metode Meneliti Hukum," Fiat Justicia, vol. 8, no. 1, pp. 15-35, 2014, doi: 10.25041/fiatjustisia.v8no1.283.

[9] M. H. Hakim, "Pergeseran Orientasi Penelitian Hukum: Dari Doktrinal Ke Sosio-Legal," Syariah J. Huk. dan Pemikir., vol. 113, no. 2, p. 105, 2016, doi: 10.18592/sy.v16i2.1031.

[10] A. E. Omarini, "Fintech and the future of the payment landscape: The mobile wallet ecosystem - A challenge for retail banks?," Int. J. Financ. Res., vol. 9, no. 4, pp. 97-116, 2018, doi: 10.5430/ijfr.v9n4p97.

[11] S. M. Pandy and M. Crowe, Choosing a Mobile Wallet: The Consumer Perspective. 2017.

[12] S. A. E. Mahani, "Profil Digital Payment Di Indonesia: Peluang dan Resiko," 2019.

[13] Lampiran Surat Edaran Bank Indonesia Nomor 18/41/DKSP Perihal Penyelenggaraan Pemrosesan Transaksi Pembayaran, vol., no. 2016, pp. 1-47.

[14] Ernawati, "Analisis Perjanjian Kerjasama Pemberian Jasa Layanan Atas Uang Tunai Antara PT. Bank ICB BUMIPUTERA, Tbk dengan PT. ALPHA EMS,” 2013.

[15] H. Nuraini, "Disparitas Putusan Pengadilan Mengenai Klausula Baku yang Dilarang Dalam Perjanjian Konsumen,” 2019.

[16] S. R. Ilhami, "Pelaksanaan perjanjian kerjasama antara pt. serasi autoraya dengan audi variasi," J. online Mhs. Fak. Huk., vol. II, no. 1, pp. 1-15, 2015.

[17] R. USMAN, "Karakteristik Uang Elektronik Dalam Sistem Pembayaran," Yuridika, vol. 32, no. 1, p. 134, 2017, doi: 10.20473/ydk.v32i1.4431.

[18] C. S. Rosul, "Hubungan Hukum Penyelenggara Payment Gateway dan Konsumen dalam Sistem Pembayaran Elektronik," Jurist-Diction, vol. 2, no. 5, pp. 1611-1630, 2019.

[19] T. Pangaribuan, "Permasalahan Penerapan Klausula Pembatasan Pertanggungjawaban Dalam Perjanjian Terkait Hak Menuntut Ganti Kerugian Akibat Wanprestasi," J. Huk. Pembang., vol. 49, no. 2, p. 443, 2019, doi: 10.21143/jhp.vol49.no2.2012.

[20] Mitigasi Risiko Pembiayaan Pada Bank Perkreditan Rakyat Syariah (BPRS) SAFIR Cabang Curup Kabupaten Rejang Lebong, "Ika Gustin Rahayu, Hendrianto," Al Falah J. Islam. Econ., vol. 3, no. 2, pp. 2-22, 2018.

[21] P. Forum, "Mobile and Digital Wallets: US Landscape and Strategic Considerations for Merchants and Financial Institutions," 2018.

[22] J. Musfirotin, "Perlindungan Hukum Terhadap Transaksi Uang Elektronik Berdasarkan Fatwa No.116/DSN-MUI/XI/2017 Tentang Uang Elektronik Syariah Oleh Bank Syariah,” JuristDiction, vol. 3, no. 1, p. 187, 2020, doi: 10.20473/jd.v3i1.17632.

[23] P. Smith, "Coping with the death of the bargain without burying the spirit of the law: A 'foundational' approach to comparative law and its application to adhesion contracts in Louisiana," LA. Law Rev., vol. 76, no. 4, pp. 1277-1337, 2016. 